\title{
Unthinkable Horror or Emerging Best Practice? Exploring Access to Special Collection Materials through Interlibrary Loan
}

This article explores the question of increasing access to restricted access collections through interlibrary loan. Surveys sent to 15 member institutions of the University of North Carolina system measured current activity levels, special collection/interlibrary loan cooperation, and willingness to expand services in this manner. Mission statements from throughout the UNC system were reviewed and found to frequently contain content supporting widespread access. Known practices are described and potential models for change are suggested and critiqued. The authors conclude that for such practices to become widespread, a concerted effort by administrators, practitioners, professional associations, and researchers will likely be required.

S eeking to improve service and access are constant topics of discussion in libraries. As online searches result in greater awareness of special or restricted collections, a movement is growing to make special collections and other restricted access materials more accessible. To address these aspects of professional practice for Special Collections, the Association of Research Libraries established a working group which produced Special Collections in ARL Libraries: A Discussion Report from the ARL Working Group on Special Collections $^{1}$ and later expanded the discussion in a web conference. ${ }^{2}$

The report and webinar led to several conversations between the authors of this article about how interlibrary loan (ILL) could work in collaboration with Special Collections to improve patron services, expand access to special collection materials, and possibly also to better utilize library employee talent and limited time. While conducting a preliminary literature review, we discovered that using interlibrary loan for special collections was not a unique idea - it appeared to be growing in acceptance, both within Special Collection and ILL circles. As residents of North Carolina, the authors investigated what the University of North Carolina system was doing in this regard by surveying our colleagues on current practices between special collections and interlibrary loan; concurrently we reviewed library literature and UNC system mission statements and websites for relevant information.

For the purpose of this article, special collections are defined as manuscripts, personal papers, rare books, and other archival materials that are usually gathered into separate collections, frequently called 'Special Collections,' under restricted access policies that often include non-circulating closed stacks and monitored reading rooms. The term restricted access is also used to describe these items, as not all of the potential survey respondents were responsible for or associated with traditional Special Collections.

\section{Literature Review}

The authors originally shared the thought that access to special collection materials through interlibrary loan was a new and untried approach.
Special Collections obviously predate modern libraries. Likewise, the practice of interlibrary loan certainly is not new, as is evidenced by letters in Library Journal from $1876^{3}$ and $1892^{4}$ championing interlibrary loan. The ILL service in the United States quickly became widespread enough to warrant the American Library Association publishing ILL guidelines over 90 years ago $^{5}$ and to warrant the creation of international guidelines over fifty years ago. ${ }^{6}$ Lending of special collections materials, however, does not have as long of an history, but specific guidelines have existed for more than 15 years to govern the provision of rare and unique materials to outside libraries. ${ }^{7}$ Even before these protocols existed, some libraries were pursuing similar objectives: the New York State Library talked about doing so in 1954; a Wisconsin network began inter-campus lending of archival materials in 1961 and Missouri similarly followed in 1978. ${ }^{9}$ RBML (Rare Book and Manuscripts Librarianship) published a special issue dedicated to this topic in $1988 .{ }^{10}$ Indeed, providing access is not just a local activity; it is a key provision in the Code of 
Ethics for Archivists. ${ }^{11}$ Yet, while such guidelines and example services created a framework to provide access to special collections through interlibrary loan, the practice appears to have remained relatively uncommon until more recently.

With the increasing standardization of collections through large e-journal packages, database subscriptions, and collection development through automated approval plans, the unique or rare materials owned by libraries are increasingly distinguishing institutions from each other, yet these special resources are frequently of limited access. Attention to this trend was brought with the release of the 2001 report, Special Collections in ARL Libraries: A Discussion Report from the ARL Working Group on Special Collections, ${ }^{12}$ and has seen continued discussion of the needs, challenges, and potential merit of what are now collectively known as "hidden collections". 13 Indeed, as Eden and Raymond conclude, special collection materials are giving libraries renewed relevance, ${ }^{14}$ but only, as Pritchard advocates, if the materials are properly cataloged for discovery and then made available for use. ${ }^{15}$ Ling talks about the "tyranny of distance"16 -- about how few patrons have the time or money to travel across the state, country, or world to research. To ameliorate some of these obstacles, the National Archives of Australia began a digitization-ondemand program of special collection materials in $2001 .{ }^{17}$

The Research Libraries Group (RLG) hosted the Sharing the Wealth forum in 2002 to discuss issues surrounding ILL and special collections ${ }^{18}$ in it, Hickerson explained Cornell's lending program in place since $1993,{ }^{19}$ Kempe explained how the Frick Art Reference Library began to lend from its collections in the mid-1990s, ${ }^{20}$ Clapinson discussed Oxford's resource sharing and digitization initiatives, ${ }^{21}$ and Snyder recounted a pilot project at UC Berkeley's Bancroft Library. ${ }^{22}$ Also at the Sharing the Wealth forum, Wright ${ }^{23}$ and Worthey ${ }^{24}$ talked about how their libraries, the Library of Congress and Stanford, respectively, were digitizing on demand; Wright shared the Library of Congress' motto for the project was "Copy Once, Access Always." During Martin's keynote address at Sharing the Wealth, he reiterated that Ranganathan's Five Laws of Librarianship include that books are to be used and that libraries should save the time of the user, with the context being that using interlibrary loan and other methods to provide access to special collections would be in keeping with these laws. ${ }^{25}$ Also in 2002, Muhlberger wrote about how the BOOKS2U! service operated by Austrian Literature Online was digitizing older books on demand. ${ }^{26}$ In 2004, Turner and Scott wrote in the Journal of Access Services summarizing a pilot project for interlibrary loaning of special collections materials within the University of California system. ${ }^{27}$ The Rethinking Resource Sharing Initiative released a manifesto in 2007 to encourage libraries to have, in part, "the lowest possible barriers to fulfillment" and to make available resources from "cultural institutions of all sorts: libraries, archives, museums...." ${ }^{28}$ Moving forward to 2009, a joint ARL/CNI/SPARC report was released that detailed nine principles for digitizing special collections materials. ${ }^{29}$ Also in 2009, OCLC Research hosted a webinar with a panel discussing their varied experiences with sharing special collection materials by interlibrary loan. ${ }^{30}$ Shrauger wrote in a 2010 article, co-written with Lee Dotson, about how "[o]pening the doors of special collections to interlibrary loan would set a new standard for research and access." ${ }^{31}$ At the 2010 ILLiad International Conference, the session "ILL for Archives and Special Collections" covered the topic's history and current state and described Shrauger's success story from the University of Central Florida. ${ }^{32}$ A follow-up session was then held at the 2011 ILLiad International Conference, ${ }^{33}$ where the new draft ACRL/RBMS combined guidelines for interlibrary loan and lending for exhibition was discussed. ${ }^{34} \mathrm{~A}$ revised draft was approved by RBMS at ALA Annual in June, 2011, and forwarded to the ACRL Board. ${ }^{35}$

\section{other, yet these special resources are frequently of limited access.}

While the literature review conducted during the 2009-2010 academic year showed that there appears to be building momentum and increasing justification throughout the profession for expanding access to special collections through interlibrary loan and digitization-on-demand, it did not reveal any publications about efforts in this arena by University of North Carolina system libraries. However, at the 2011 International ILLiad conference, it was announced that UNC-Chapel Hill libraries are developing a policy to address ILL and Special Collections (G. Holliday, 
personal communication, March 24, 2011). Recognizing that there has been little previous formal effort to increase or improve services in this manner throughout the state of North Carolina encouraged us to move forward with our investigation, including developing a survey on factors affecting implementation of ILL of restricted collection materials and a review of available mission statements within the UNC system libraries.

\section{Mission Statement Review}

Having found no formal publications about the UNC system making restricted access materials available by interlibrary loan, the next order of business was to look at the institutions' public information to determine how each defined its purpose. Universities, like most organizations, operate with limited resources and must prioritize which programs and services they offer. These decisions are often based on their individual mission statements and the resulting strategic planning. The University of North Carolina operates as a multi-campus university comprised of 17 quasiindependent institutions, including 15 general universities. ${ }^{36}$ Two campuses were excluded from our review: UNC School of the Arts, which has a limited focus and small enrollment, and the North Carolina School of Science and Mathematics, which is a residential school for 11 th and 12th grade students. Since the University of North Carolina at Chapel Hill is often referred to simply as "UNC," the phrase "UNC system" is frequently used throughout the state to refer to all campuses, a distinction we continue in this article. The mission of the UNC system is "to discover, create, transmit, and apply knowledge to address the needs of individuals and society." 37 The UNC system's mission continues: "This mission is accomplished through instruction [...]; through research, scholarship, and creative activities, which advance knowledge and enhance the educational process; and through public service [...]. In the fulfillment of this mission, the University shall seek an efficient use of available resources to ensure the highest quality in its service to the citizens of the State" [emphasis in original]. ${ }^{38}$

Since the UNC system values the communication of knowledge, service to improve the state, and efficiency, expanding access to special collections materials using cost-effective methods would appear to be encouraged, at least tangentially, at the university system level.

Seeking evidence of how each campus interpreted the manner in which the UNC system mission is applied locally, the mission statements of each institution and, when available, of their respective academic libraries and special collection operations were reviewed as published on their websites. Our review looked for wording that showed an emphasis on serving patrons outside the institution, on spreading knowledge, and on access beyond the campus. Whether by a reference to being in service to "those who pursue knowledge" 39 or "services and programs to the community, including the military, and other educational institutions throughout North Carolina, the nation, and the world," ${ }^{40}$ or some other variation of a similar concept, all mission statements reviewed address some aspect of the idea that doing more to better serve patrons, especially those in North Carolina, is a primary pursuit. Seven of the 15 universities' mission statements were found to specifically mention service to the state and region, four to their communities, and only one to the general public. Only 13 of the main academic libraries throughout the system had posted statements, of which three support public service, two their universities' missions, two the state, two their communities, two their regions, and one distance users. Nine restricted/Special Collection mission statements were located: three promote access, two service to the region, and one to the state; one specifically noted its cooperation with other institutions. Several statements in each category employ more than one of these terms. Anecdotally, outside of the survey, one colleague shared that the department head at that person's institution frequently made statements about "serving the people of [the region]" within the larger idea of "being in service to the People of North Carolina" and even the forthright assessment "we are a state school-the collection belongs to the citizens of the state."

No ILL mission statements were located on any of the libraries' websites. We take that to indicate that the mission statement of the library or, in cases when the library does not offer an overt statement, the campus's statement gives inspiration and guidance for their activities, which are normally governed administratively with the day-to-day focus on fulfilling requests and meeting library goals.

\section{Survey Explanation}

The authors decided to create a survey to send to their respective colleagues in interlibrary loan and special collections at the 15 general universities in the UNC system. In drafting the survey, it was decided that two separate, targeted surveys would be easier and faster for each audience to complete. The surveys were first distributed in May 2010, during the end of the spring semester 
when it was anticipated that the end of the academic year might provide recipients enough of a reduced daily workload to complete the surveys before turning their attention to preparing annual reports. The surveys were sent electronically using the Qualtrics software to email addresses gathered from websites through the UNC system website. ${ }^{41}$ PDF versions of both sets of questions along with some referenced resources were made available to participants on a project website. ${ }^{42}$ When responses were not forthcoming after several weeks, reminder emails were sent and the deadline extended, moving deep into the summer months.

Even with reminders and extensions, we closed the surveys with less than half of the invitees having responded. While such results are typical for such an instrument, we were concerned about the value of the information collected; yet, some interesting trends emerged from the data. Notably, more Special Collection contacts responded than ILL contacts. We originally thought that ILL contacts, who provide materials to outsiders daily, would readily reply, whereas Special Collection contacts, who are mostly accustomed to providing materials for in-house use and to preserving materials, might be more skeptical about the topic and thus less likely to complete the survey. Analyses of the two surveys are presented in the following sections. While the information gained is perhaps of limited statistical significance, the results provide insights into the concerns of individual respondents who are active practitioners.

\section{Special Collections Survey Summary}

The Special Collections survey was emailed to the 13 contacts throughout the UNC system who were identifiable as having relevant responsibilities for restricted collections; two UNC schools had no readily identifiable recipient for the survey. Eight surveys were begun, but by the final question only six respondents were active. The survey was 41 questions long with several being multipart, such as identifying available equipment or classifying patrons by status (faculty, staff, graduate students, et al.) Responses are described numerically rather than by percentages to provide a clearer representation of the available information, as describing four responses as $57 \%$ did not seem a fair representation of the data.

Four had not read Special Collections in ARL Libraries: A Discussion Report from the ARL Working Group on Special Collections or participated in or viewed the online discussion reviewing the report; two said it had been read and two said it had not been reviewed in detail. At the onset, one was willing to consider changing their practices, one was not, and six were unsure. Four respondents had discussed providing special collections materials by interlibrary loan prior to this survey. Seven restricted access collections detailed actively providing loans and copies from special collections. Fees were referenced by four of seven respondents to the question, "What restrictions are there on the use of copies or other reproductions of restricted access/special collection materials?" While the nature or quality of the relationship between ILL and those responsible for restricted collections was not addressed directly, four of seven indicated that the handling of requests for ILL of restricted materials was "uncertain," which suggests vague or tenuous interactions. Five participants indicated that their manuals or policies that govern ILL or special collections were available online, and two provided information in the text block field on the survey.

Three said they would be very unlikely to lend special collection materials to other institutions, two were undecided and one responded as being very likely to consider the practice. Four were unlikely to offer access to restricted materials from other institutions in their own search rooms. Table 1 details the equipment available for reproduction of restricted access materials. The responses suggest a solid infrastructure for reproduction of restricted access items by approved operators, which will be discussed further below.

\begin{tabular}{|l|c|}
\hline & Response \\
\hline combination photocopier/scanner & 6 \\
\hline 11 ” x 17" size & 5 \\
\hline color scanner & 5 \\
\hline 8.5 " x 11" size & 4 \\
\hline digital camera, handheld & 3 \\
\hline overhead scanner & 3 \\
\hline flatbed scanner & 3 \\
\hline digital camera, stand mounted & 2 \\
\hline microfilm duplication machine & 2 \\
\hline scanning by other department(s) & 2 \\
\hline microfiche duplication machine & 2 \\
\hline other - please explain & 1 \\
\hline 17 ” 23-3/8” size & 1 \\
\hline photocopier only (no scanners) & 1 \\
\hline larger than 17” x 23-3/8” & 0 \\
\hline high-speed book scanner & 0 \\
\hline
\end{tabular}

Table 1: Equipment Available in Special Collection Areas for Reproduction of Restricted Access Materials

In response to other questions in the survey, one respondent specified that items identified as rare books were not photocopied and two replies indicated having received a loan of restricted access materials, but only one instance was subsequently described in replies 
to the relevant questions. The most encouraging response was the three respondents who indicated that since considering the questions in this survey it was "very likely" that requests for restricted materials via ILL would be investigated. The survey's design only allows the researchers to know that two of the three had not previously discussed this possibility.

\section{ILL Survey Summary}

The ILL survey was emailed to 15 ILL contacts throughout the UNC system. Seven libraries began the survey, but only three completed all 19 questions. Two had not read Special Collections in ARL Libraries: A Discussion Report from the ARL Working Group on Special Collections or participated in or viewed the online discussion reviewing the report; one said it had read the report and one said it had only skimmed it. Two were willing to consider changing their practices, one was not, and one was unsure. Three had discussed providing special collections materials by interlibrary loan prior to this survey, but only one actively provides loans and copies from restricted collections. While two do not charge for interlibrary loan, two others charge some libraries outside of the UNC system to borrow from them; one library stated that it charges its patrons for at least some interlibrary loan requests. Three ILL offices claim a close relationship with special collections, whereas one indicated that it does not have much of a relationship. No participants forwarded their manuals or policies that govern ILL or Special Collections, as the survey requested. Three said being in the UNC system made them more likely to scan or lend special collection materials to other UNC libraries. Three libraries expressed concern over the cost of special shipping services, the use of special packaging supplies, and the requirement of insurance; two were concerned over having to use special shipping services, special handling processes, and the cost of special supplies. Additionally, single respondents identified lacking staff time and knowledge of handling special collection materials, having to charge special lending fees, and having to negotiate lending terms. Responses were split between requirements and preferred restrictions regarding the handling of loans (see Table 2).

In terms of equipment, three have a flatbed scanner, two have a color scanner, and two have a microfiche duplication machine available. One library asked if there were a software package that could be used to better manage requests between ILL and Special Collections and wondered how ILL operations could "convince special collections that such collaboration would be in both of our benefits." These are worthy questions that need further investigation and discussion.

\section{Current Process at One UNC Campus}

To better understand the possible benefits that collaboration between Special Collections and Interlibrary Loan could bring, one must understand the process now frequently in use. The current process at one UNC institution - where one of the authors is a faculty member - and comparable to many other libraries in

\begin{tabular}{|l|c|c|c|c|}
\hline & $\begin{array}{c}\text { Should be } \\
\text { Required }\end{array}$ & $\begin{array}{c}\text { Preferred } \\
\text { Restriction }\end{array}$ & $\begin{array}{c}\text { Neither Required } \\
\text { nor Preferred }\end{array}$ & Responses \\
\hline Make in-library-use only & 1 & 2 & 0 & 3 \\
\hline $\begin{array}{l}\text { Make in-library-use only in the borrowing library's special } \\
\text { collections reading room or with other supervision }\end{array}$ & 0 & 2 & 1 & 3 \\
\hline Make in-library-use with a proctor or other supervision & 0 & 0 & 3 & 3 \\
\hline Use courier shipping (e.g. FedEx or UPS) & 2 & 0 & 1 & 3 \\
\hline Use extra shipping insurance & 1 & 1 & 1 & 3 \\
\hline $\begin{array}{l}\text { Shipping in boxes with bubble wrap (e.g. no peanuts, paper fluff, } \\
\text { newspapers) }\end{array}$ & 2 & 1 & 0 & 3 \\
\hline Limit to faculty or graduate students only & 0 & 2 & 1 & 3 \\
\hline Charge extra lending fees for processing & 1 & 1 & 1 & 3 \\
\hline Have special signed releases or use agreements by the patron & 1 & 1 & 1 & 3 \\
\hline $\begin{array}{l}\text { Have special signed releases or use agreements by the borrowing } \\
\text { institution }\end{array}$ & 0 & 1 & 1 & 2 \\
\hline $\begin{array}{l}\text { Have special signed releases or use agreements by the patron and } \\
\text { the borrowing institution }\end{array}$ & 1 & 0 & 1 & 2 \\
\hline
\end{tabular}

Table 2: Potential Restrictions for Off-Site Lending of Restricted Material 
the authors' experiences, is for Interlibrary Loan personnel to receive requests for special collections materials and to cancel the requests with a note directing libraries to contact the local Special Collections department directly. When borrowing libraries follow through to contact Special Collections, they must download a request form from that departmental website, complete the form, submit the form, wait for an estimate of the cost of the photocopy or loan (if applicable), print, sign and submit a use agreement (restricting publication and/or requiring a citation to the holding library), pay in advance by check or credit card (which the Circulation Department has to process), and then wait for the material to be duplicated by Special Collections' employees (see Figure 1). These tasks are accomplished along with their other tasks of helping on-site patrons in the reading room, processing new materials, teaching instruction classes on the collections, and preserving the materials. Interlibrary Loan personnel currently must also go through this process with Special Collections whenever any patron wants materials from the restricted access collections, whether an outside library requesting interlibrary loan service or a local patron requesting document delivery service. This is a cumbersome process that forces individual patrons and borrowing libraries, as well as our Interlibrary Loan's and Special Collections' staffs, to complete many steps. On the other hand, if these patrons or libraries want a copy from a book or journal in the general collections, they can enter their request in the online ILLiad system, then Interlibrary Loan employees can pull items, send loans by mail or provide scans or copies within a day or two for free without additional forms or consultations (see Figure 2). Since local patrons and borrowing libraries rarely know if what they want is in the general collections or special collections, there is confusion and delay; they do not understand why sometimes the library is fairly easy and quick to use and other times it is not.

Some progress in this area has been made in the past few years at the author's institution. ILL has received
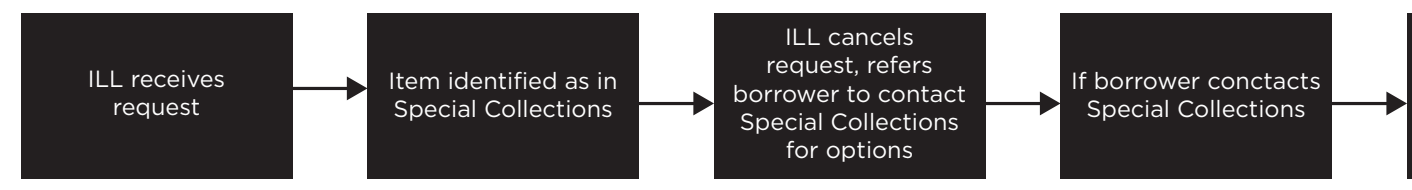

Special Collections sends request form to borrower or

directs borrower to an online form

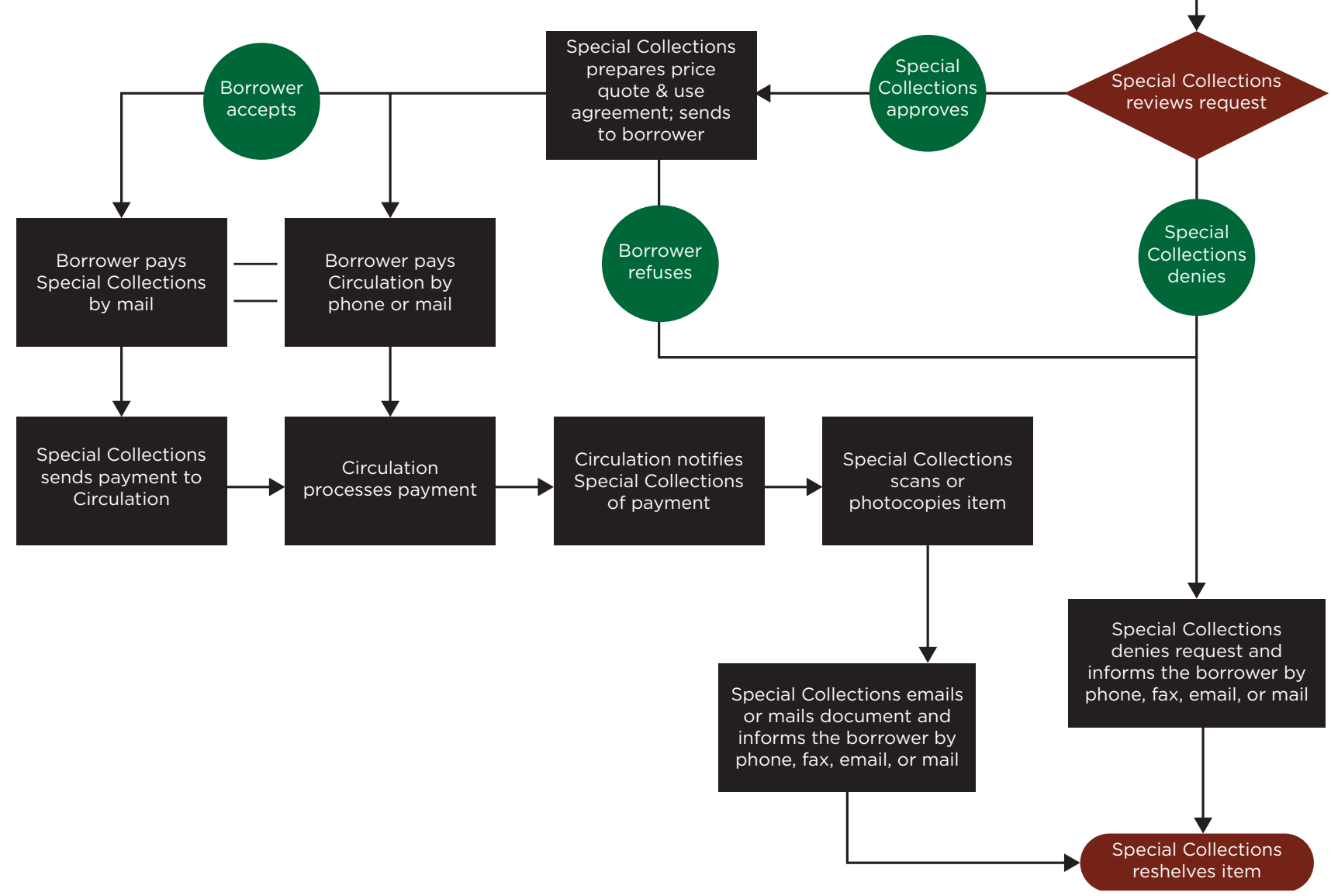

Figure 1: Current Process for Interlibrary Loan Requests for Most Special Collections Materials 


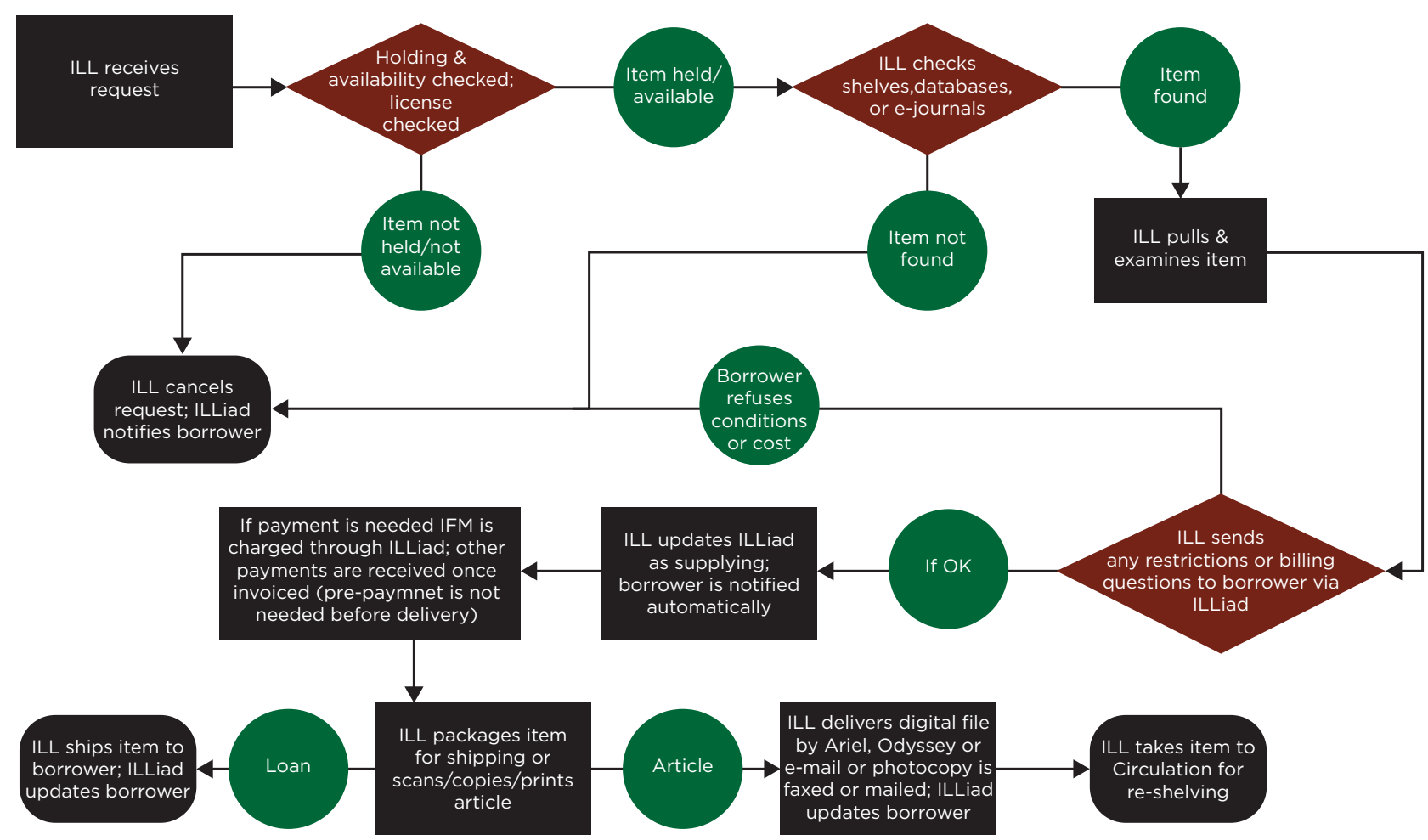

Figure 2: Current Interlibrary Loan Lending Process for Non-Special Collections Materials

approval to scan from select journal runs in special collections and select archive materials (e.g. yearbooks and dissertations) rather than directing borrowing libraries to contact Special Collections directly. ILL also was once permitted to scan from a newsletter housed in a restricted access collection for a distance education patron. The process for these requests is that the borrowing libraries or patrons place their requests through interlibrary loan; ILL confirms the material is in the allowed special collection areas, and asks special collection staff to pull the materials, which are then immediately taken to ILL for scanning and then returned immediately to Special Collections (see Figure 3). In contrast, the usual process for ILL for materials from the general collection is to pull the materials, leave them stacked on carts awaiting scanning (sometimes overnight in the ILL office), and then place them in Circulation to await re-shelving, which can be a several day process.

\section{Implications}

While those surveyed did not provide voluminous data, the information gathered when combined with the literature review, mission statements, and an observation of current practices does suggest some points of consideration. Libraries have many unique materials housed in our special collections that, if made more accessible, could be integrated into our shared understanding of human history. OCLC Research released a document entitled "Support for the Research Process" in 2009 that sets forth a ten-point "call to action" for academic libraries in particular, including that libraries should "design flexible new services around those parts of the research process that cause researchers the most frustration and difficulty" 43 and that libraries should "find ways to demonstrate to senior university administration, accreditors, and auditors the value of library services and resources to scholarship." ${ }^{44}$ Surely some of the most frustrating parts of research can include being referred between various library departments at one's home institution and/or at other institutions, raising funds to travel to consult research materials, rushing through research with limited travel time, and paying and waiting for loans or duplications; providing special collection materials through interlibrary loan could help mitigate these concerns. Additionally, providing loans and scans of rare items could expand the use of the collections, which could quantify their value. Another benefit would be that having reciprocal relationships with other lending libraries could help researchers at one's home institution to have higher quality research produced more quickly at a lower cost. If libraries value our collections and want people to use them, we need to make them available to distance researchers, whether by loan, copies, scan-on-demand, or mass-digitization. 
As library budgets are increasingly scrutinized and as researchers, taxpayers, donors, and granting agencies increasingly demand greater access and accountability, we anticipate programs that lend interlibrary loan special collection materials will be more widely implemented, likely modeled on the successful programs previously cited. Libraries have made great progress in recent decades with cataloging special collection materials and with creating electronic finding aids so patrons can more easily and remotely discover what exists in our collections. Libraries have created digital resources from small portions of collections to help increase access and to reduce the wear on fragile items. The time is now to greatly expand access to special collection materials, be it through scan-ondemand services, interlibrary loan, or ILL-driven scan-on-demand services. Many ILL operations have automated networked request management systems, automated fee management services, specialized scanning equipment, electronic delivery software and servers, and the packaging areas and supplies needed to provide special collections materials to others.

With examples previously discussed of libraries providing special collection materials beyond the institution in the past fifty years, even before overnight courier services and automated management systems existed, there must be methods for libraries to coordinate such services today. Developing a work-flow and service model for interlibrary loan to provide restricted access materials can be accomplished multiple ways. Figure 4 illustrates several options for processing. It has ILL staff receiving the request, then sending the request to special collection personnel to review and pull approved materials. At that point either ILL or special collection personnel could handle negotiations for cost or use. Then ILL could process the request by copying or packaging, or special collections or another department could do so -- whichever is deemed to have

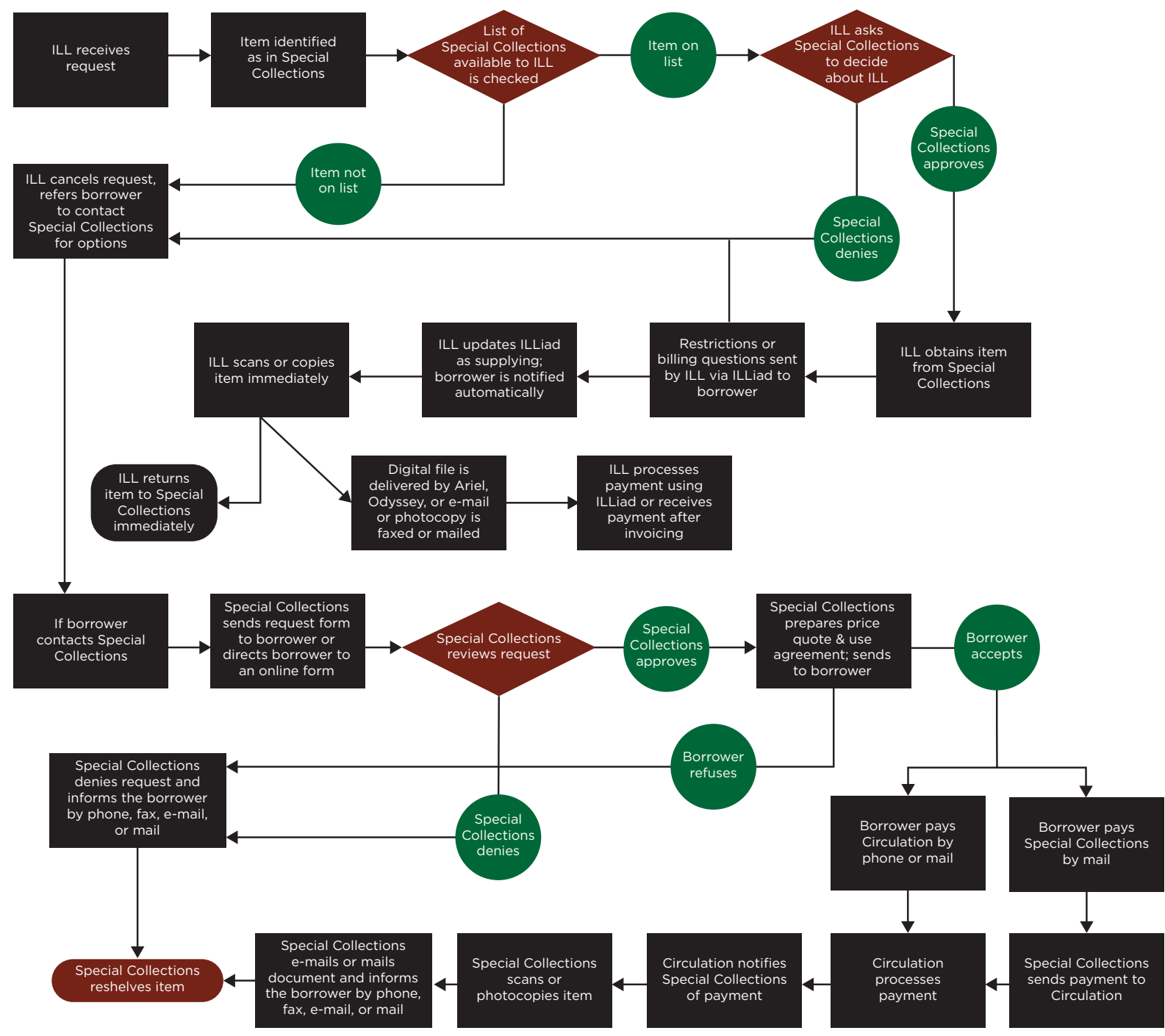

Figure 3: Current Process for Interlibrary Loan Requests for Select Special Collections Materials 
the better equipment or supplies, the most time, and/or the appropriate staff. No matter which department physically scans or packages the item, ILL is the department that handles the request tracking, delivery, and payment. Even if the reproduction of the materials remains within the restricted collection's purview, delivery and compensation being handled by the ILL department would represent a delegation of responsibilities more in keeping with each department's respective strengths. As can be seen from this example, collaboration between Interlibrary Loan and Special Collections does not require a single model to be followed by all libraries - each institution may determine which work-flow best meets its situation.

Implementing ILL best practices for special collection materials within the UNC system would represent significant progress towards increased fidelity to our governing mission statements, which charge us to "an efficient use of available resources to ensure the highest quality in its service to the citizens of the State"; ${ }^{45}$ such strategic alignment might also apply to other libraries. Each institution can develop policies and procedures which maintain individual standards of stewardship. ILL offices have worked hard for decades to streamline their work-flows, to advance the use of automated request management and payment systems (e.g. Atlas Systems' ILLiad and OCLC's IFM respectively), and to scan for electronic delivery whenever possible. Special Collections' staff are typically less accustomed to providing duplication services. ILL at the author's library has the capacity to scan materials with a low risk of damage to the items, to receive and reply to requests electronically, to fulfill requests with digital scans quickly,

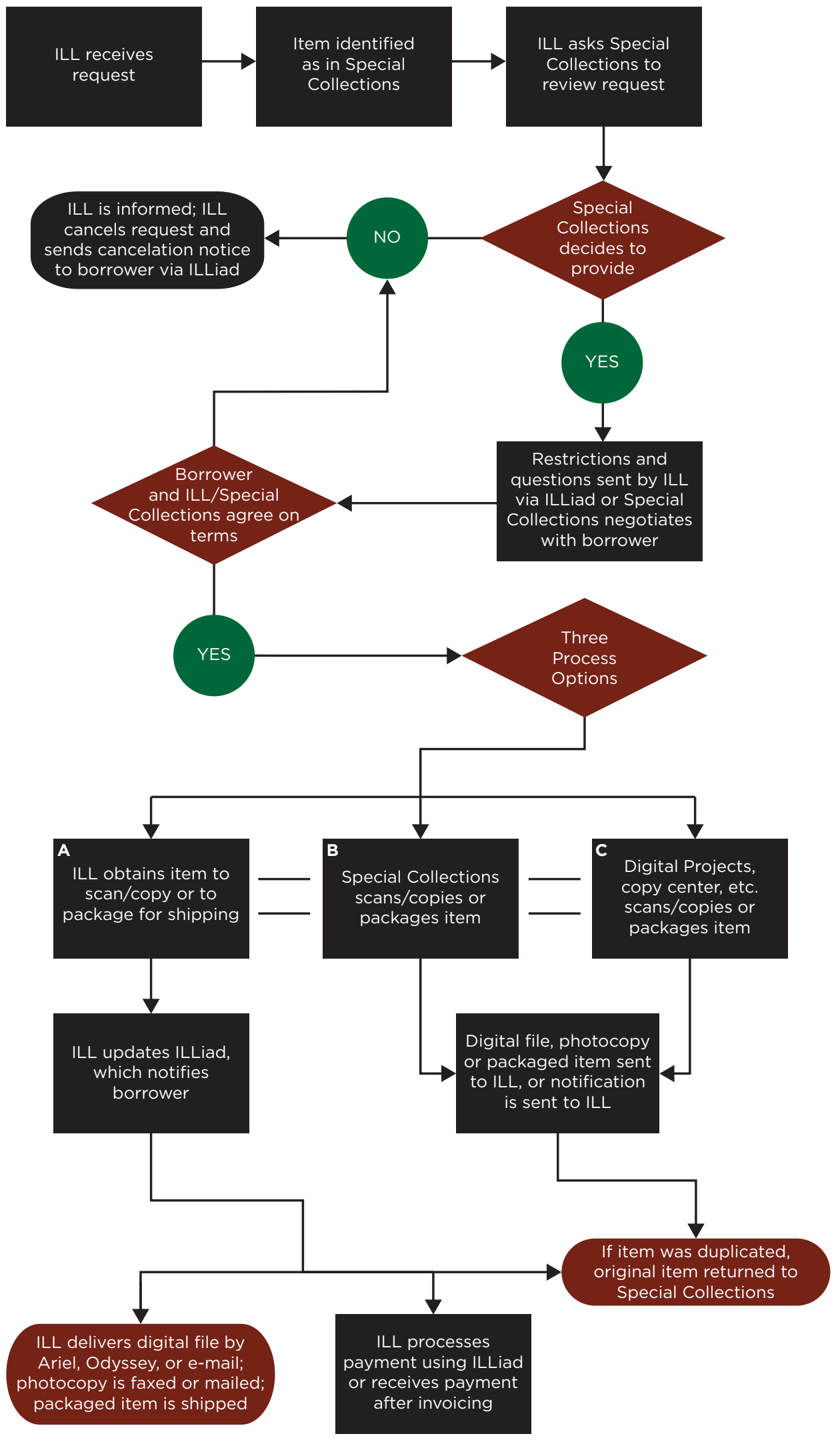

Figure 4: Alternative Special Collections/Interlibrary Processes 
and to receive automated payments by IFM, through our database-driven invoice system, or, from international libraries, with the receipt of IFLA vouchers ${ }^{46}$ that ILL can then reuse when it borrows materials from other international libraries. The idea of letting each area of the library focus on the functions where it excels appeals to these investigators: let ILL process requests and payments and, when the nature and condition of the materials allow it, scan or loan restricted access materials; such a division of labor would allow Special Collections' personnel to focus on the processing, cataloging, and preservation of restricted access materials, as well as to instruct patrons and to assist them with their research.

By advocating for Special Collection and ILL cooperation, we do not seek to minimize the very real concerns for material security or for the difficulties in implementing an ILL or digitization service for special collection items. Martin said " $\mathrm{t}]$ here has always been-and there will always be-an inherent tension between the preservation of library materials and the use of those materials." ${ }^{47}$ Shrauger and Dotson note that ILL/DD Services and Digital Services at the University of Central Florida had very different work methods and goals that had to be resolved for them to provide special collections items. ${ }^{48}$ We heartily agree that ILL operations tend to provide goodenough copies quickly for one-time use, whereas digitization operations most often strive to provide highquality scans with complete metadata for long-term multi-patron access and preservation. Dupont provided some guidance in starting a service at the 2010 Western Roundup; ${ }^{49}$ more detailed advice can be found in most of the articles previously cited, especially Ling's, Shrauger's, and those in Sharing the Wealth. We also note that, from our perspective, Special Collections have typically focused on in-person resource consultation, with the occasional one-time use photocopy provided as time or researchers' budgets allow; whereas ILL and digital services have typically had less in-depth consultations with patrons - they instead have primarily focused on providing timely, highvolume processing of requests.

\section{Conclusion}

However any institution might determine what is the appropriate response to the idea of providing interlibrary loan services for restricted access materials, the critical point is to begin the discussion as soon as possible among Interlibrary Loan and Special Collections personnel and our patrons. While the University of North Carolina system is not currently leading the way in providing access to special collection materials through interlibrary loan, our surveys did show that there was some interest in investigating expanding services in such a manner, and our review of the UNC system's mission statements found that sharing knowledge and serving those outside the local institution were common themes. A fascinating recurrent topic emerged from the literature: interinstitution loaning and copying of materials has been discussed with regard to refining, improving, and expanding services for 135 years. ${ }^{50}$ Discussions of this sort focusing on providing special collections by interlibrary loan have been occurring for at least fifty years, ${ }^{51}$ even as interlibrary loan has expanded its material offerings -- from lending only books, to photocopying articles, to lending films and VHS tapes, to lending CDs and DVDs, and to faxing and scanning articles, relatively few special collections materials have been made available through the service.

To accomplish this mutually beneficial advancement, special collection and interlibrary loan employees need to talk more with each other, to form new work-flows, and to lobby software companies to create options for needed features to aid collaboration (e.g. additional limitation fields on interlibrary loan requests, special fee options, and the ability to send/ receive loan agreement contracts automatically). Library administrators, campus leaders, university system leaders, legislators, professional associations, and most importantly patrons and researchers need to advocate and push for greater collaboration on the meta-level. While sometimes discomforting, difficult, and expensive to implement, such system-wide approaches are often the most effective way to foster collaboration, enhance access, and improve efficiency. Certainly this was the case in the author's experience with the recent UNC System Virtual Library Catalog and Resource Sharing project, which attempted to create a shared virtual catalog, to provide a uniform ILL system for all member universities, to provide an expedited delivery service between the campuses, and to spur a collection review process to identify subject areas of emphases at each campus and to reduce duplicated materials throughout the system (personal communications, 2008-2010). Such collaboration needs constant support, though. The referenced expedited courier service was adopted throughout the UNC system while a two-year grant funded it; as soon as the grant funding ended, the majority of the libraries ceased shipping using the courier. Likewise, the shared ILL system concept was replaced by having the UNC system libraries not already using the ILLiad 
interlibrary loan management system implement the stand-alone software rather than having all implement a single, networked system. These two examples offer lessons for collaborative initiatives -- radical change is not sustainable without a unified vision implemented through concerted, long-term, system-wide effort that is backed by sufficient resources.

The urge to be conservative, to protect rare or unique items, or to avoid risk may overwhelm the ability to discern the greater good to be gained from change. The most effective possibilities for the UNC system and beyond will be developed, refined, and sustained from all stakeholders meeting together to continue to improve the existing standards, codes, and benchmarks that govern providing special collection items through interlibrary loan and to craft new ones as needed; one significant step is the approval of new guidelines for interlibrary and exhibition loan of special collection materials by RBMS at ALA Annual 2011. ${ }^{22}$ Some institutions, states, and consortia have found various methods to provide special collection materials to others, in some cases for decades, so models and results are available to consult. The goal should be to allow researchers easier, faster, cheaper, and fuller access to restricted access materials. As we move further into a new century, we must continually strive to measure our progress not through competition, but by an increased ability to serve. Our patrons are waiting on us!

\section{References}

${ }^{1}$ Association of Research Libraries Working Group on Special Collections, "Special Collections in ARL Libraries: A Discussion Report from the ARL Working Group on Special Collections," March 2009, <http:// www.arl.org/bm $\sim$ doc/scwg-rfeport.pdf> (accessed July 26, 2011).

${ }^{2}$ Association of Research Libraries, Alice Prochaska, moderator. "Transformative Issues for Special Collections in ARL Libraries, 2010," July 7, 2009, <http://www.youtube. $\mathrm{com} /$ watch?v=fdS6-RKuNBY\&feature=youtube gdata_player> (accessed July 26, 2011).

3 Samuel Green, "The Lending of Books to One Another by Libraries," Library Journal 1:1 (1876): 15-16.

${ }^{4}$ Bunford Samuel, "Mutual Book Lending Between Libraries," Library Journal 18: 9 (1892): 373-374.

5 ALA RUSA STARS, "Interlibrary Loan Code for the United States Explanatory Supplement," 2008, <http://www.ala.org/ala/mgrps/divs/rusa/resources/ guidelines/interlibraryloancode.cfm $>$ (accessed July 26, 2011); ALA RUSA STARS, 2008. "Interlibrary Loan Code for the United States."<http://www.ala.org/ala/ mgrps/divs/rusa/resources/guidelines/interlibrary.cfm> (accessed July 26, 2011).

${ }^{6}$ International Federation of Library Associations and Institutes, "International Resource Sharing and Document Delivery: Principles and Guidelines for Procedure," n.d., <http:/www.ifla.org/en/publications/ international-resource-sharing $>$ (accessed July 26, 2011).

7 Association of College and Research Libraries, "ACRL Guidelines for the Interlibrary Loan of Rare and Unique Materials (2004)," June 2004, <http://www.ala.org/ala/mgrps/divs/acrl/standards/
ALA_print_layout_1_192700_192700.cfm> (accessed July 26, 2011).

8 Bernard Halloran Dollen, "Inter-library loan policy and special collections of the college and university libraries in the state of New York," The Bookmark 15, no. 6 (1956): 1-13.

9 Christian Dupont and Kristine Shrauger, "ILL for Archives and Special Collections: Enhancing Access to Unique and Rare Materials," presented at the 2010 ILLiad International Conference, Virginia Beach, VA, 2010. <http://www.slideshare.net/christiandupont/2010-illiad-conference-dupont-ill-and-special-collections> (accessed July 26, 2011).

${ }^{10}$ Alice Schreyer, ed., Rare Books and Manuscripts Librarianship 3, no. 2 (Fall 1988), <http://www.rbms. info/publications/rbml/tables_of_contents.shtml> (accessed July 26, 2011).

${ }^{11}$ Society of American Archivists, "Code of Ethics for Archivists" (Society of American Archivists, February 5, 2005), <http://www2.archivists.org/code-of-ethics> (accessed July 26, 2011).

${ }^{12}$ Judith M.Pantich, "Special Collections in ARL Libraries: Results of the 1998 Survey Sponsored by the ARL Research Collections Committee" (Association of Research Libraries Research Collections Committee meeting, Washington D.C., 2001), <http://www.arl.org/bm doc/spec_colls_ in_arl.pdf> (accessed July 26, 2011).

${ }^{13}$ American Library Association, Association of College and Research Libraries (ACRL), "Special Collections in ARL Libraries: A Discussion Report from the ARL Working Group on Special Collections" (Washington, D.C.: Association of Research Libraries, 2009).

${ }^{14}$ Bradford Eden, "New Information Landscape: Technical 
Services Futures. Navigating the New Frontier" (presented at the North Carolina Library Association Resources \& Technical Services Section 2010 Fall Workshop North Carolina Library Association, Greensboro, NC, September 30, 2010), <http://www.nclaonline.org/ sites/default/files/documents/rtss/KeynoteEden $\% 20$ NCLA\%20presentation.ppt> (accessed July 26, 2011); Linda Raymond, "Technical Services Today: 'Living with the New Normal'” (presented at the North Carolina Library Association Resources \& Technical Services Section 2010 Fall Workshop North Carolina Library Association, Greensboro, NC, September 30, 2010).

${ }^{15}$ Sarah M. Pritchard, "Special Collections Surge to the Fore," Libraries and the Academy 9, no. 2 (2009): 177-180.

${ }^{16}$ Ted Ling, "Why the Archives Introduced Digitisation on Demand," RLG DigiNews 6, no. 3 (June 15, 2002), <http://worldcat.org/arcviewer/1/ OCC/2007/08/08/0000070519/viewer/file2881.html> (accessed July 26, 2011).

${ }^{17}$ Ibid.

${ }^{18}$ Research Library Group. RLG Programs, "2002 RLG Members Forum: Sharing the Wealth," n.d., <http://worldcat.org/arcviewer/1/ OCC/2007/09/28/0000073852/viewer/file489.html> (accessed July 26, 2011).

${ }^{19} \mathrm{H}$. Thomas Hickerson, "Expanding Access to Special Collections: National and International Cooperation" (powerpoint presented at the RLG Member Forum, Washington D.C., October 18, 2002), <http://worldcat. org/arcviewer/1/OCC/2007/09/28/0000073852/ viewer/file1 161.ppt> (accessed July 26, 2011).

${ }^{20}$ Deborah Kempe, "Sharing Unique and Rare Materials at the Frick Art Reference Library" (powerpoint presented at the 2002 RLG Members Forum: Sharing the Wealth, Washington D.C., October 18, 2002), <http://worldcat. org/arcviewer/1/OCC/2007/09/28/0000073852/ viewer/file291.ppt> (accessed July 26, 2011).

${ }^{21}$ Mary Clapinson, "The Past, Present, and Future of Lending the Bodleian Library's Special Collections" (powerpoint presented at the RLG Members Forum: Sharing the Wealth, Washington D.C., October 18, 202AD), <http://worldcat.org/arcviewer/1/ OCC/2007/09/28/0000073852/viewer/file485.html> (accessed July 26, 2011).

${ }^{22}$ Susan Snyder, "Testing the Waters: Report on a Pilot Project for Sharing Special Collections" (powerpoint presented at the RLG Members Forum, Washington D.C., October 18, 2002), <http://worldcat.org/ arcviewer/1/OCC/2007/09/28/0000073852/viewer/ file481.html> (accessed July 26, 2011).

${ }^{23}$ ChrisWright, "Library of Congress Document Delivery Over the Internet" (powerpoint presented at the RLG Member Forum, Washington D.C., October 18, 2002), <http://worldcat.org/arcviewer/1/ OCC/2007/09/28/0000073852/viewer/file322.ppt> (accessed July 26, 2011).

${ }^{24}$ Glen Worthey, "Digital Delivery of Interlibrary Loan: building the collections we share, sharing the collections we build" (powerpoint presented at the RLG Member Forum, Washington D.C., October 18, 2002), <http://worldcat.org/arcviewer/1/ OCC/2007/09/28/0000073852/viewer/file1228.ppt> (accessed July 26, 2011).

${ }^{25}$ Robert Martin, "Keynote Address" (speech presented at the RLG Members Forum, Washington D.C., October18, 2002), <http://worldcat.org/arcviewer/1/ OCC/2007/09/28/0000073852/viewer/file483.html> (accessed July 26, 2011).

${ }^{26}$ Günter Mühlberger, "Digitising instead of mailing or shipping: a new approach to interlibrary loan through customer-related digitisation of monographs," Interlending \& Document Supply 30, no. 2 (2002): 66-72.

${ }^{27}$ Deborah Turner and Kerry Scott,"Interlibrary Loaning Special Collections: A Test Run for the University of California," Journal of Access Services 2, no. 2 (2004): 23.

${ }^{28}$ Rethinking Resource Sharing Initiative. "Rethinking Resource Sharing”, 2009, <http://www. rethinkingresourcesharing.org/> (accessed July 26, 2011).

${ }^{29}$ Anne R. Kenney, The Collaborative Imperative: Special Collections in the Digital Age, A Bimonthly Report from ARL, CNI, and SPARC, Research Library Issues, December 2009, <http://www.arl.org/resources/pubs/ rli/archive/rli267.shtml> (accessed July 26, 2011).

${ }^{30}$ Jennifer Schaffner and Dennis Massie. "Treasures on Trucks and Other Taboos: Rethinking the Sharing of Special Collections," June 5, 2009, <http://www5.oclc. org/downloads/programsandresearch/parcasts/2009052 8Schaffner\&Massie.mp4> (accessed July 26, 2011).

${ }^{31}$ Kristine J. Shrauger and Lee Dotson, "Scan by Numbers: Interlibrary Loan Lending Statistics Shape Digital Initiative," Journal of Interlibrary Loan, Document Delivery \& Electronic Reserve 20, no. 3 (July 2010): 136, 135-148, <http://www.tandfonline.com/doi/abs/10.10 80/1072303X.2010.488517> (accessed July 26, 2011).

${ }^{32}$ Dupont, Christian and Kristine Shrauger. "ILL for Archives and Special Collections: Enhancing Access to Unique and Rare Materials" (presented at the 2010 ILLiad International Conference, Virginia Beach, VA, 2010), 
$<$ http://www.slideshare.net/christiandupont/2010-illiad-conference-dupont-ill-and-special-collections > (accessed July 26, 2011).

${ }^{33}$ Christian Dupont and Denise Forro, "Borrowing and Lending Special Collections: New Guidelines, New Practices, New Horizons" (Conference Session presented at the 2011 ILLiad International Conference, Virginia Beach, VA, March 24, 2011), <http://www.atlas-sys.com/ Conference2011/Presentations/BorrowingandLending SpecialCollections.pdf> (accessed July 26, 2011).

${ }^{34}$ Association of College and Research Libraries Rare Book and Manuscripts Section Task Force, "ACRL/RBMS Guidelines for borrowing and lending special collections materials for research use and exhibition. 2011" (RBMS Task Force for the Guidelines for Borrowing and Lending Special Collections Materials, April 1, 2011), <http:// rbms.info/committees/task_force/borrowing/RBMS _ Borrowing-Lending_Draft_4-1-11.pdf> (accessed July 26, 2011).

${ }^{35}$ Association of College and Research Libraries, Rare Book and Manuscripts Section of American Library Association, "ACRL/RBMS Guidelines for Borrowing and Lending Special Collections Materials," June 26, 2011, <http://rbms.info/committees/task_force/ borrowing/RBMS_Borrowing-Lending_Draft $\% 20$ SAC_approved.pdf> (accessed August 15, 2011).

${ }^{36}$ University of North Carolina, "Our 17 Institutions," About the University, n.d., <http://www.northcarolina. edu/campus_profiles/index.php> (accessed July 26, 2011).

${ }^{37}$ University of North Carolina, "Statement of Mission," History and Mission, n.d., <http://www.northcarolina. edu/about/mission.htm> (accessed July 26, 2011).

${ }^{38}$ Ibid.

${ }^{39}$ Carol Grotnes Belk Library and Information Commons Appalachian State University Library, "Appalachian State University Library Mission and Vision," Appalachian State University Library Mission and Vision, October 2007, <http://www.library.appstate.edu/admin/mission. html> (accessed July 26, 2011).

${ }^{40}$ Fayetteville State University, "Fayetteville State University Mission Statement and Vision Statement," Mission Statement - Fayetteville State University, n.d., $<$ http://www.uncfsu.edu/mission.htm> (accessed July 26, 2011).

${ }^{41}$ University of North Carolina, "Our 17 Institutions," About the University, n.d., <http://www.northcarolina. edu/campus_profiles/index.php> (accessed July 26, 2011).

${ }^{42}$ Authors, 2010.
${ }^{43}$ Chris Bourg, Ross Coleman, and Ricky Erway. 2009. Support for the Research Process: An Academic Library Manifesto. Report produced by OCLC Research. <http://www.oclc.org/research/publications/ library/2009/2009-07.pdf> (accessed July 26, 2011).

${ }^{44} \mathrm{Ibid}$.

${ }^{45}$ University of North Carolina, "Statement of Mission," History and Mission, n.d., <http://www.northcarolina. edu/about/mission.htm> (accessed July 26, 2011).

${ }^{46}$ International Federation of Library Associations and Institutes, "IFLA Voucher Scheme", 2009, <http:// archive.ifla.org/VI/2/p1/vouchers.htm> (accessed July 26, 2011).

${ }^{47}$ Robert Martin. "Keynote Address" (presented at the RLG Members Forum, Washington D.C., October18, 2002), <http://worldcat.org/arcviewer/1/ OCC/2007/09/28/0000073852/viewer/file483.html> (accessed July 26, 2011).

${ }^{48}$ Kristine J. Shrauger and Lee Dotson, "Scan by Numbers: Interlibrary Loan Lending Statistics Shape Digital Initiative," Journal of Interlibrary Loan,Document Delivery \& Electronic Reserve 20, no. 3 (July 2010): 135148, <http://www.tandfonline.com/doi/abs/10.1080/10 72303X.2010.488517> (accessed July 26, 2011).

${ }^{49}$ Christian Dupont. "'Enhancing Access to Archives and Special Collections through Inter-Library Loan" (session presented at the Western Roundup: A Joint Conference of the Conference of Inter-Mountain Archivists, Northwest Archivists, Society of California Archivists, and Society of Rocky Mountain Archivists, Seattle, WA, 2010), <http://www.slideshare.net/christiandupont/ enhancing-access-to-special-collections-throughinterlibrary-loan> (accessed July 26, 2011).

${ }^{50}$ Samuel Green. "The Lending of Books to One Another by Libraries," Library Journal 1:1 (1876): 15-16; Bunford Samuel, "Mutual Book Lending Between Libraries," Library Journal 18: 9 (1892): 373-374.

${ }^{51}$ Bernard Halloran, "Inter-library loan policy and special collections of the college and university libraries in the state of New York," The Bookmark 15, no. 6 (1956): 1-13.

${ }^{52}$ Association of College and Research Libraries, Rare Book and Manuscripts Section of American Library Association, "ACRL/RBMS Guidelines for Borrowing and Lending Special Collections Materials," June 26, 2011, <http://rbms.info/committees/task_force/ borrowing/RBMS_Borrowing-Lending_Draft $\% 20$ SAC_approved.pdf> (accessed August 15, 2011). 